\title{
Reader-Response Theory: A Path Towards Wolfgang Iser ${ }^{1}$
}

\section{(La teoría de la recepción: una ruta hacia Wolfgang Iser)}

\author{
Alejandra Giangiulio Lobo² \\ Universidad Nacional, Costa Rica
}

\begin{abstract}
Reader-response theory is studied from the perspective of different authors and literary critics to characterize the different types of readers, according to each approach, the reading process and the creation of meaning. The essay centers on Wolfgang Iser's phenomenological approach to reader response, creation of meaning and types of readers.

\section{resumen}

Se estudia la teoría de la recepción a partir de diferentes autores y críticos literarios, para caracterizar los distintos tipos de lectores, según cada aproximación y los procesos de lectura y creación de significado. El ensayo se centra en el enfoque fenomenológico de Wolfgang Iser sobre la recepción del lector, la generación de significado y los tipos de lectores.
\end{abstract}

Keywords: reader-response theory, Wolfgang Iser, reading process, meaning Palabras clave: teoría de la recepción, Wolfgang Iser, proceso de lectura, significado

Reader-response theory focuses mainly on the readers and their relationship with the text to create or generate meaning. The analysis of reader-response theory spans many decades, encompassing different schools of thought. Though different authors and literary critics deal

$1 \quad$ Recibido: 17 de febrero de 2013; aceptado: 10 de julio de 2013.

2 Escuela de Literatura y Ciencias del Lenguaje. Correo electrónico: giangiulio@gmail.com

$$
L_{\text {etras }} 54 \text { (2013), ISSN 1409-424X; EISSN 2215-4094 }
$$


with reader response in their own way, the interest of this study is to focus on Wolfgang Iser's phenomenological approach, his proposed readers and their creation of meaning.

Reader-response criticism is almost one hundred years old, if one excludes the classical awareness and concern that Plato and Aristotle had on the audience's reactions through the use of rhetoricthe act of persuasion with words - or if one obviates the natural, yet intrinsically personal, reaction any reader has to a text when reading without thinking of critical theories or specific meanings. In close to a century, reader-response criticism has seen changes and evolved; different ideologies have merged and contributed dilemmas and clarifications. As a critical approach, reader-response analyzes - without giving importance to the simplicity of the explanation - the response of the readers towards a text. Jane P. Tomkins defines reader-response criticism as "not a conceptually unified critical position, but a term that has come to be associated with the work of critics who use the words reader, the reading process, and response to mark out an area of investigation." 3 This definition reveals reader response as a theory that joins other theories dealing with the reader's response to a text. In fact, all reader-response critics share common ground on analyzing both text and reader to reach meaning. The way meaning is acquired or developed will mark the break from one specific methodology in reader-response to the next, but as Lois Tyson writes:

reader-response theorists share two beliefs: (1) that the role of the reader cannot be omitted from our understanding of literature and (2) that readers do not passively consume the meaning presented to them by an objective literary text; rather they actively make the meaning they find in literature. ${ }^{4}$

3 Jane Tompkins, ed., Reader-Response Criticism (Baltimore: Johns Hopkins University Press, 1994) ix.

4 Lois Tyson, Critical Theory: A User-Friendly Guide, 2nd. ed. (New York: Routledge, 2006) 170. 
In regard to meaning, Charles E. Bressler points out that "Meaning $[\ldots]$ is context-dependent and intricately associated with the reading process. Like literary theory as a whole, several theoretical models and their practical applications exist to explain the reading process"5; therefore, the critic notes that though each reader-response model approaches the analysis of a specific text differently, all raise similar questions about the reading process and, in summary, about the way a reader reaches or attains the meaning of that text. Bressler includes many of these questions in his chapter on reader-response criticism, trying to portray the wide array of possibilities the different models of reader-response criticism can bring into consideration. Some focus more on the reader and on his or her reading process, others focus on the text and its weight on the reader, and still others concentrate on the author and his or her attitudes toward the reader and the intentions of a text. Bressler's final words on the assumptions of reader-response criticism are that "The concerns, then, of reader-response critics can best be summarized in one question: What is and what happens during the reading process?"

To answer this question Bressler proposes studying the following factors: reader, text, and meaning. First, the reader has to be seen not only as the person reading, but also his or her world knowledge, background, viewpoint, reason for reading, and knowledge of words and literature must be taken into account. Second, the study of the text must include what Bressler calls "linguistic elements," which include word choice, syntax and sentence formation, among others. Third, meaning has to be regarded from the interaction or transaction between the reader and the text. These three elements together would bring forth the study of the response of readers and would give

5 Charles Bressler, Literary Criticism: An Introduction to Theory and Practice (New Jersey: Prentice Hall, 2003) 61.

6 Bressler, 62.

15 Bressler, 62. 
different emphasis to one of these aspects in particular to develop the various methodologies or models of reader-response criticism.

The primary distinct reader-response methodologies or groups of study are structuralism, reception theory, subjective criticism, social reader-response theory, and phenomenology. To begin with, the linguist Ferdinand de Saussure developed the concept of structuralism in the early twentieth century. His theories and notions influenced many scholars from different areas, such as the anthropologist Claude Lévi-Strauss, the semiotician Roland Barthes, and the Russian formalist Viktor Shklovsky. Structuralist critics analyzed the text scientifically, just as they approached language. The main objective of their analysis was to find certain codes in a text that would generate meaning. For this theoretical approach, the symbols or archetypes in literature are part of a larger set of signs that are evident and pre-established in culture and society. The task of a knowledgeable structuralist critic is to find the pattern of signs in a text and translate their meanings to the public. However, this translation has to follow a specific societal context (depending on which society the text is related to and the codes assigned to it) for it to make sense. Therefore, each text contains in itself its own meaning, which has to be de-coded or translated by the reader. For this methodology, readers tend to be rather emotionally passive because they are meant to discover the purpose or meaning of a text through a scientific method, thus eliminating any possibility of textual plurality.

Within the structuralist branch of reader-response criticism, the school of New Criticism arose around the mid-twentieth century with figures such as William K. Wimsatt and Monroe Beardsley. The New Critics advocated close reading of texts, avoiding biographical information of authors or other external sources that could help in the textual analysis. According to Charles Bressler, "[the] New Critics believed the text would reveal its own meaning. Extrinsic factors, such as historical or social context, mattered little"; therefore, the text, not

8 Bressler, 58. 
the reader, was mainly the only source of the meaning. This view was completely structuralist, yet the New Critics knew that the text could have many effects on the reader, who had to remain passive, since the reader could not bring any personal experience or emotion to the textual analysis. As a structuralist reader-response critic I.A. Richards is a key figure. Richards believed that a scientific method would lead him to the textual meaning. His widely known experiment of giving poems with no title or author to his university students, so they would record their answers, is the best proof of his adherence to structuralism. After recording the responses of his students, and analyzing the different and even incompatible answers, he reached the conclusion that a structural approach was the only way a person could attain the truth of a poem. The result of detaching oneself from the emotion of the poem would be a pseudo-statement, which responded to the person's appetencies or desires. Science or a structuralist approach, on the other hand, is objective. First and foremost is that the poem contains all the necessary information to reach its adequate interpretation. The fact that the poem would satisfy the reader's appetencies comes second.

The break with structuralism began with Louise M. Rosenblatt, who since the 1930s, had denied the authority of the text over the reader, or as Bressler points out: "Unlike the New Critics, [Rosenblatt] shifts the emphasis of textual analysis away from the text alone and views the reader and the text as partners in the interpretative process." Rosenblatt's main tenet is the notion of the transactional experience between the reader and the text, where the text brings past experiences back to the reader, but at the same time the text is shaping those emotional experiences by selecting and ordering the ideas in a well-structured way. In other words, during the reading process there is emotion to be taken into account, but the creation of meaning is still restricted to some probable meanings within the text. According to Rosenblatt, a poem is produced each time reader and text come

9 Bressler, 60. 
together during the transactional experience, which would be different from the text itself. The poem arises from aesthetic reading, one of the two categories Rosenblatt proposes for the types of reading that could exist. For her, efferent reading is reading for information, while aesthetic reading is reading to experience the text. The text can bring forth different reactions since "The text acts as a stimulus for eliciting various past experiences," 10 but according to Rosenblatt, the possibilities are not endless; therefore, the number of correct interpretations is limited.

The shift that Rosenblatt creates is monumental in the advance of reader-response criticism, because from that moment on, the text is not the only creator of meaning, and the reader has more relevance and importance. Yet, structuralism still has some weight on readerresponse criticism, with Gerard Prince and his notion of narratology and narratee. For Prince, the narratee is "someone whom the narrator addresses," 11 the person to whom the voice is narrating the story, and in literature, both narrator and narratee are fictional creations. Prince came up with the notion of narratee because he thought that most critics were concerned about the narrator but forgot the receptor of the story. He also points out and defines the three types of readers: the real reader, the virtual reader and the ideal reader. The real reader is the person who is actually reading the text, book in hand, concentrating on the words, silently — or not — reading the words printed. This reader is not fictitious. The virtual reader is the possible person for whom the author writes, unless the writer is writing for himself or herself. According to Prince, "Every author [...] develops his [or her] narrative as a function of a certain type of reader whom he [or she] bestows certain qualities, faculties, and inclinations according to his [or her] opinion of men in general and according to the obligations he [or she] feels should be respected." 12 Finally, the ideal reader is the one who

\footnotetext{
$10 \quad$ Tompkins, 60.

11 Tompkins, 7.

12 Tompkins, 9.
} 
would understand perfectly what the writer intends to communicate and who would agree with the writer's ideology and perception of life. In all, the narratee cannot be any of these readers because first, the narratee is not the person who buys or picks up a book to read. Second, since the narratee is fictitious, the writer is not writing with this narratee-person in mind, but for someone who can relate to what he or she wants to say. Third, the narratee does not need to understand completely what the author says while the narration takes place.

Gerard Prince explains what the "zero-degree narratee" is by describing what this person can do in the text. The zero-degree narratee would know the tongue and language of the narrator; in other words, he or she would know the meanings of signs and grammatical elements used by the narrator. Since the narratee can follow the narrative, he or she knows the events presented by the narrator through the order presented to him or her in the narration. Besides, the narratee has no personality or social characteristics that would be present in the narration since he or she cannot emit an opinion or disagree with what is being said. The narratee has to have an excellent memory to recall what was narrated previously, but he or she must be somewhat unfamiliar with the characters, so the narrator would have a purpose in narrating the story. Finally, there can be multiple narratees in a text, just as there can be multiple narrators, depending on the whim or purpose of the author. Moving forward, Prince also presents the functions of the narratee. The narratee becomes the mediator or the link between the author/narrator and the reader. With the aid of the narratee, through explanations or asides, the reader understands better the characterization made by the narrator. In addition, the reader can discover the importance of a certain theme through the same narrator-narratee relationship; therefore, by studying this relationship, the reader can pinpoint the author's message and intention in writing the text.

Another reader-response theory is that of subjective criticism, which has been developed by David Bleich. For this critic, the text is formed by readers' responses since "there is no literary text beyond 
the meanings created by readers' interpretations and $[\ldots]$ the text the critic analyzes is not the literary work but the written responses of readers." ${ }^{13}$ For Bleich there are real and symbolic objects. While real objects are accounted for physically, like books or printed pages, symbolic objects represent the experience of reading and interpreting those books or printed pages. For him, reading is symbolization; that is, the perception or identification which takes place during the reading experience creates a symbolic world in the minds of readers. When a reader interprets a text, according to Bleich, he or she is interpreting his or her own symbolization; therefore, interpretation is a resymbolization of the reading experience. According to him, in a general sense responses can be categorized into two types: readerand reality-oriented. A reader-oriented response would be about the reading experience. Tyson notes that "they are confined largely to comments about the reader's memories, interests, personal experiences, and the like." ${ }^{14}$ On the other hand, reality-oriented responses deal with expressing personal opinions on moral and social issues, rather than focusing on personal experiences. But Bleich favors a third form of response, which is experience oriented, because it combines both of the above types of response: the reader's reaction to specific moments in the text, and his or her opinion of characters, events or passages from the text.

Norman Holland is another follower of subjective criticism and uses it from a psychological perspective, focusing on "what readers' interpretations reveal about them, not about the text." ${ }^{15}$ For Holland, readers respond to literature the same way they respond to events in their past and present lives. According to Tyson:

Holland calls the pattern of our psychological conflicts and coping strategies our identity theme. He believes that in our daily lives we

\begin{tabular}{ll}
\hline 13 & Tyson, 178. \\
14 & Tyson, 179. \\
15 & Tyson, 182.
\end{tabular} 
project that identity theme onto every situation we encounter and thus perceive the world through the lens of our psychological experience. Analogously, when we read literature, we project our identity theme, or variations of it, onto the text. ${ }^{16}$

Therefore, the reading experience brings forth interpretations charged with personal fears, needs, desires and objections, depending on each reader and his or her life situation. Hence, interpretation is less intellectual and academic, and more psychological and personal.

Moving on to a less personal form of reader-response, Stanley Fish is the precursor of social reader-response theory. For Fish, there is no individualistic response to a text, but rather a product of the work of the interpretative community to which the reader belongs. The interpretative community would be the social group sharing the interpretative strategies a reader brings to texts when he or she reads them. This interpretative community is the result of institutionalized assumptions from established social groups such as schools, colleges, the church, religions, and the government. These communities dictate "what makes a text a piece of literature [...] and what meanings [readers] are supposed to find in it." ${ }^{17}$ Fish believes that a reader comes to a text already predisposed to interpret it in a certain way depending on the interpretative communities that this reader belongs to. Thus, interpretations can change throughout history, as social, political and religious forces change, evolve, arise, or disintegrate through the passage of time.

Finally, phenomenology, mainly developed by Wolfgang Iser and Hans Robert Jauss, is a reader-response theory that emphasizes the perceiver and perception process over the text. Phenomenology is the study of "phenomena,"18 or the study of the objects as they appear in people's experiences (or the way people experience and gather meaning) and things. Objects such as a literary text must be

16 Tyson, 183.

17 Tyson, 185.

18 Phenomena are observable occurrences, and are therefore perceived through a person's senses or mind. 
experienced so they can exist. According to Bressler, "Objects can have meaning, phenomelogists maintain, only if an active consciousness (a perceiver) absorbs or notes their existence," 19 an idea that proves the critical importance of the existence of the reader in order to give meaning to the text. It is said that modern phenomenology was developed by Edmund Husserl, a philosopher from the late nineteenth to early twentieth century. In philosophy, phenomenology is concerned with the interpretation of phenomena by the human consciousness. In literary terms "the true poem can exist only in the reader's consciousness, not on the printed page." ${ }^{20}$ When reader and text interact or transact, meaning is created, and this transaction exists only in the consciousness of the reader.

In the case of Hans Robert Jauss, he is associated with reception theory, which arose in the late 1960s. Reception theory deals with the reader's reception of a literary text. Jauss proposes that when interpreting a given text, its social components and historical background must be taken into account; therefore, readers from different time periods can have valid, yet different interpretations of the same text. Jauss uses the term "horizons of expectation" to explain that each reader must be aware of the different assessments one could have in history.

A reader, according to Jauss, will come up with a way of judging of a text that will be dependent on the historical period of time he or she belongs to. Bressler notes that "since each historical period establishes its own horizons of expectations, the overall value and meaning of any text can never become fixed or universal." ${ }^{21}$ The previous idea clashes then with structuralist approaches, where meanings and interpretations were fixed according to the time and taste of the critic.

In literary criticism, phenomenology was developed by the German theorist and critic Wolfgang Iser (1926-2007). He worked as a professor in many European and American Universities - such as the

19 Bressler, 65.

20 Bressler, 65.

21 Bressler, 66. 
University of Constance and the University of California, Irvinewhere he taught English and Comparative Literature. He became one of the most prominent literary theorists of the twentieth century because of his contributions and significant ideas on reader-response criticism. In the late 1960s he founded with Jauss the Constance School of Reception Aesthetics. His critical works have influenced many other critics, and his later work explores the findings after thirty years of criticism, in a sort of literary anthropology. Jane P. Tompkins describes him as having "formulated a theory of the reader's role in creating literary meaning." ${ }^{22}$ Thus, his relevance is clear and still influential in literary criticism. Another important result of Iser's theories is the development of a system to describe the reader's experience in reading. According to Tompkins:

Iser's phenomenology of the reading process, with its movement from anticipation to retrospection, its making and unmaking of gestalts, ${ }^{23}$ like Prince's taxonomy of readers and narratees, provides critics with a new repertoire of interpretative devices and thus brings to light a new set of facts for observation and description. ${ }^{24}$

In general terms, Iser and other phenomenologists believe that an object can have meaning only if it has been recognized or registered through someone's consciousness. In terms of literature, a text and a reader become one at the moment of reading, when the reader takes the text into his or her consciousness and emits a response or effect. Thus, Iser proposes that the critic should not attempt to explain a text, but rather study the reaction of the reader and the effect the text had on him or her.

22 Tompkins, 274.

23 Iser uses the term "gestalt" because it refers to a structure, configuration or pattern of physical, biological, or — in Iser's case — psychological phenomena so integrated as to constitute a functional unit with properties not derivable by sum of its parts. Therefore, Iser's use of gestalt psychology responds to his study of perception and behavior from the standpoint of an individual's response.

24 Tompkins, $\mathrm{xv}$. 
In the essay "The Reading Process: A Phenomenological Approach" Iser presents the method utilized in phenomenological reading. First, he states that to analyze a text, one must take into account the reactions to it; therefore, the reader becomes as important as the text, and the text must be concretized into the reader's consciousness. Parting from this, Iser proposes two types of literary works: artistic and aesthetic. The former would be the original creation of the author, and the latter would be the realization process produced by the reader after reading the artistic creation. Hence, what Iser denominates literary work is the point where the text and the realization ${ }^{25}$ of the reader meet:

The convergence of text and reader brings the literary work into experience, and this convergence can never be pinpointed precisely, but must always remain virtual, as it is not to be identified either with the reality of the text or with the individual disposition of the reader. ${ }^{26}$

This personal and individual — or for Iser, virtual — connection between reader and text is dynamic because the text presents the reader with an array of perspectives and patterns that the reader must use and relate to, elements that have to be somewhat unknown to him or her, for reading to be entertaining. The reader's imagination must be attracted and engaged for the realization process to become one that is active and creative, serving the personal purpose of the reader. In a novel, for instance, an insignificant detail for one reader can be the delight for another, yet this reaction is as varied because readers have different tastes and interests, but the point is that there is always some element - trivial or capital - that lures readers into dynamic reading.

25 For Wolfgang Iser, the term "realization" refers to the act of reading, when the text is being realized within the reader's consciousness.

26 Wofgang Iser, The Implied Reader: Patterns of Communication in Prose Fiction from Bunyan to Beckett (Baltimore: Johns Hopkins University Press, 1978) 275. The page numbers of further quotations from The Implied Reader will be indicated in parentheses with the quoted text. 
Iser's second objective in his essay is to attempt to explain the psychological endeavors taken into a phenomenological analysis. His first step is to study the way sequent sentences work upon other sentences. For this, Iser uses Roman Ingarden's idea of intentional sentence correlatives, a chain of sentences with intentional meaning and correlation, which unite to form more complex units that end up creating a world within the literary work. Iser notes that the world presented to the reader does not show him or her everything necessary, but rather only glimpses that the reader must interact with and realize. Reinforcing the significant role of imagination, Iser states that "the literary text needs the reader's imagination, which gives shape to the interaction of correlatives foreshadowed in structure by the sequence of the sentences" (277). Although the imagination of a reader can run as fast and as far as the reader lets it, the text's correlatives would only permit a reasonable amount of expectation for the reader, because if imagination and expectation ran wild, a text could never fulfill them.

Another psychological matter studied by Iser is that of the impact of memories on the reader. Whatever is stored in the reader's memory can appear and either add to or take from a reading, given the connections made by the reader. Since no memory can be exactly the same as the original event which created it, a memory is enriched each time it comes forth with whatever background that called it to the reader's attention. With memory, only more complex connections can be made: "the reader, in establishing these interrelations between past, present and future, actually causes the text to reveal its potential multiplicity of connections" (278). The connections made between the reader's real memories and the events in a text which recalled those memories are sole proof of how the text and reader interact in a creative process to bring forth meaning: "The product of this creative activity is what we might call the virtual dimension of the text, which endows it with its reality. This virtual dimension is not the text itself, 
nor is it the imagination of the reader: it is the coming together of text and imagination" (279).

Apart from imagination, which is different for each reader, Iser notes that in the flow of sentences in a text there are omissions or gaps presented to the reader that can create exasperation and frustration because the text is not following the path that the reader has intended to take. Knowing that this will always happen in the reading process, especially because the reader has no real contact with the author, Iser dismisses this concern by admitting that the omissions in the text provide the text with dynamism, "Thus whenever the flow is interrupted and we [the readers] are led off in unexpected directions, the opportunity is given to us [readers] to bring into play our own faculty for establishing connections - for filling in the gaps left by the text itself" (280). In other words, these gaps represent the best opportunity for the reader's imagination to foreshadow, fulfill doubts, comment and expect. Again, there can be as many ways to fill a gap as there are readers; for that reason, the innumerable realizations created by readers cannot exhaust the textual meaning or its possible effects on readers.

In addition, Iser proposes that readers must realize the existence of a time sequence in each text since no complete chain of actions can be understood in a single moment. As the reading process takes place, the reader must be aware that his or her perspective will definitely move when constructing and linking the different events and elements of the text. For example, Iser calls the moment of a second reading of a text "innovative reading" (281) because the reader comes to a text for a second time with knowledge of the plot, but with a different perspective, and will notice elements that were not realized before, and put others into the background. The time sequence would have changed since, "The time sequence that [the reader] realized on his [or her] first reading cannot possibly be repeated on a second reading, and this unrepeatability is bound to result in modifications of his [or her] experience," (281) making it innovative, a "new" reading for the reader. 
Summing up the reading process, Iser notes that reading brings forth the basic patterns of real experience:

In whatever way, and under whatever circumstances the reader may link the different phases of the text together, it will always be the process of anticipation and retrospection that leads to the formation of the virtual dimension, which in turn transforms the text into an experience for the reader. The way in which this experience comes about through a process of continual modification is closely akin to the way in which we gather experience in life (281).

The text, for Iser, becomes a mirror that reflects the reader's experiences and dispositions. Nevertheless, what a reader realizes is never exactly like reality; otherwise, he or she would be bored by reading something so familiar. The reading process brings forth personal and individual aspects of the reader only to enrich the experience; it may be similar or even familiar, but never the same. Yet again, this self-recognition on the part of the reader depends on how willing someone is to participate, share, link and fill in the text.

Iser concludes his essay on the phenomenological approach to reading by clarifying the three aspects that form the reading process: "the process of anticipation and retrospection, the consequent unfolding of the text as a living event, and the resultant impression of life-likeness" (290). Iser recommends that texts be and remain "open" because this characteristic would challenge the reader to seek consistency and learn new things. In the search for consistency and making selections, the reader is said to become "entangled in the text-'gestalt' that he himself [or herself] has produced" (291), but at the same time, to get away or defeat the entanglement, readers would leave behind their own preconceptions of life and self. Iser notes: "Reading reflects the structure of experience to the extent that we must suspend the ideas and attitudes that shape our own personality before we can experience the unfamiliar world of the literary text" 
(291); in other words, during the reading process, the reader lets go of himself or herself to be immersed in the text, therefore experiencing it as a complete experience.

Having studied the phenomenological process according to Iser, it is fair to move on to his notion of the implied reader, a fundamental factor in his theory. To introduce this term, Iser first admits the existence of many different readers, "invoked when the literary critic makes pronouncements of the effects of literature or responses to it." ${ }^{27}$ Iser categorizes these readers into two types: real and hypothetical. The real reader, for Iser, is known to others because his or her reactions have been documented. The hypothetical reader is the one whose realizations of the text are possible and could be projected. This type of reader can be divided into ideal and contemporary readers. The real reader is more academic, representing the responses of a specific reading public which have been recorded. Since these responses are taken from a group, they would project the cultural codes that enabled them. For example, when a text belonging to a different time period from that of the real reader is studied, the analysis will address the codes that the real reader had according to the respective time period and the corresponding interpretations of the time period of the text. The contemporary reader can be subdivided into three categories: one that is real and historical, whose existence has been recorded in historical documents; and two hypothetical readers, one produced after the study of the historical and social knowledge of the time of its existence, and the other produced by the assumed role the text had been projected for (28).

For Iser, the ideal reader "remains nothing more than a cultured reader - if only because an ideal reader is a structural impossibility as far as literary communication is concerned" (28). Iser believes that it is impossible for a reader to have the same "code" or knowledge as

27 Wofgang Iser, The Act of Reading: A Theory of Aesthetic Response (Baltimore: Johns Hopkins University Press, 1980) 27. The page numbers of further quotations from The Act of Reading will be indicated in parentheses with the quoted text. 
the author, a preposterous idea because then the reading process would be a type of one-way communication, since there is nothing new the reader could learn from the author. Iser believes then, that being an ideal reader represents capturing all the possible realizations or meanings a text can have, personally and historically speaking. Moreover, Iser considers this previous idea fastidious and ruinous for literature, since the text would be sort of wasted away by the ideal reader. Finally, Iser states that the ideal reader "is a purely fictional being" (29), unreal yet helpful, for he or she can be the know-it-all.

Iser mentions three other critics who have attempted to come up with non-traditional and unrestrictive theories for the reader: Michael Riffaterre, Stanley Fish and Erwin Wolff. Riffaterre's idea of a superreader equals that of a group of informants who as an assembly decode the various messages of the text - semantically or pragmatically. Fish presents the informed reader who is provided by a capability of language, semantic knowledge, and literary skills. Finally, Wolff's intended reader is the one the author had in mind when writing the text, be it an idealized version, or a conjunction of the values and norms of an audience from a specific historical period. Iser finishes this study of previous readers by pointing out what these concepts have in common: "[the readers] all see themselves as a means of transcending limitations of 1) structural linguistics, 2) generative-transformational grammar, or 3) literary sociology, by introducing the figure of the reader" (34). With so many referents before him, Iser formulated his own theory: the implied reader.

Acknowledging the imperious importance of the reader, Iser sets forth to specify his implied reader that would cover everything necessary for a literary text to work properly. Mainly for this reason, Iser defines the implied reader as the one who is "firmly planted in the structure of the text; he is a construct and in no way to be identified with any real reader" (34). Iser is very precise in this last point because he uses the implied reader as a helping structure that will precede any real recipient, forming or realizing meaning in an encompassing form 
for possible readers who can be ignored or excluded by the text. Iser continues as he states that "the concept of the implied reader designates a network of response-inviting structures, which impel the reader to grasp the text" (34), so the implied reader becomes a sort of liaison between the real reader and the text. Apart from this, Iser proposes two interrelated aspects of the implied reader: the reader's role as a textual structure and the reader's role as a structured act. For Iser, a structured act refers to his idea that "the reader's role is prestructured by three basic components: the different perspectives represented in the text, the vantage point from which he joins them together, and the meeting place where they converge" (36). Iser clarifies that "By bringing about a standpoint for the reader, the textual structure follows a basic rule of human perception, as our views are always of a perspective nature" (38). Because of the reader's standpoint, he or she can construct meaning as guided by the text, with the use of the imagination and particular background. Finally, Iser concludes the following: "The concept of the implied reader offers a means of describing the process whereby textual structures are transmuted through ideational activities into personal experiences" (38). This means that the reader takes the textual structures, constructing and converting them into a personal explanation for the text.

After this analysis, Wolfgang Iser's theory of reader response can be applied to a literary work to study and be used to recognize the traits of the different types of readers present in the text and their responses. This sort of analysis becomes necessary when one must deal with the reading process and the formation or creation of meaning. In this way, characters can be studied with the readers proposed by Iser, pinpointing their distinctive traits and responses, in order to visualize how they create meaning from their respective reading processes. 